\title{
Shaping Colonial Behaviours: Franciscan Missionary Literature and the Implementation of Religious Normative Knowledge in Colonial Mexico (1530s-1640s)
}

\author{
David Rex Galindo
}

\section{$1 \quad$ Introduction}

In 1643, bishop of Michoacán Fray Marcos Ramírez de Prado, a Franciscan friar, conducted a long inspection of his diocese three years after his arrival to its seat in Valladolid (now Morelia). As a result, Ramírez de Prado wrote a series of ordinances or mandates to be observed throughout the diocese. The document, which was approved and signed by King Philip IV, reveals some abuses and negligence of his diocesan clergy, his views on indigenous Catholicism in Michoacán as well as his reformation plans to address shortcomings. Overall, he gave an adverse portrayal of the state of Catholicism in his bishopric. Fray Marcos lamented that neither parishioners nor doctrina Indians - those indigenous people still under the stewardship of missionaries - fulfilled the sacramental precepts; there was no decorum in the religious services; and a uniform legal regulation of discipline for the whole diocese was lacking. While he accepted that the flock was large and the ministers were few, Fray Marcos was particularly concerned with the administration of sacraments and the pastoral care of the indigenous communities. He reminded clerics to administer the sacraments - Eucharist, extreme unction, penance, and matrimony - in a timely and proper manner. This meant that his subjects should acquire a verifiable knowledge of the Catholic doctrine before partaking in the sacramental life as Christians. Priests had to hear confessions at least once a year during Lent to fulfil the annual confession requirement. He also urged clerics to check the bride and groom's single state and consanguine requirements to prevent incestuous relations. Michoacán's bishop concluded that priests ought to teach and regularly remind their flock of the path towards salvation through the Christian Gospels and by loving virtues and loathing vices. In other words, as exemplary mirrors and as religious guides, priests should mould the daily lives of their parishioners. Overall, the document is filled with mandatory 
precepts that would regulate the daily lives of his parishioners as much as the cadre of clerics under his authority. ${ }^{1}$

Ramírez de Prado's mandates underpinned a specific normative space to be followed in the diocese over which he ruled. From a juridical viewpoint, his instructions formulated but one layer of various normative levels that regulated the lives of the Spanish monarch's subjects in the early modern Hispanic world. Instructions by ecclesiastical authorities like Ramírez de Prado belonged to the Spanish system of administration of justice that rested on the interpretation and application of customary law, casuistry, legal codes, ecclesiastical normativities, and ius commune. Such an early modern multi-normative system or "plurality of rules", to use Paolo Prodi's words, relied on various juridical sources and practices in both the forum internum and the forum externum that represent the sacred and secular realms. At the backbone of the legal systems of the early modern monarchies were therefore competing juridical practices and normativities that championed the legal text as much as the customary praxis. Concomitantly, canon law, its treatises, and ecclesiastical practices were an essential part of such multinormativities that governed early modern people in Europe. ${ }^{2}$

In Spanish America, this legal culture adapted to and coalesced with local indigenous legal practices and the effervescence of regulations contingent with the colonial process, all of which resulted in a distinct normative regime that has traditionally been identified as "Derecho indiano". ${ }^{3}$ Studying the formation of the Spanish colonial legal system in America, scholars have put much attention to investigate the resulting legal institutions, colonial juridical agents and, more recently, how indigenous actors and other colonial subjects not only relied on but also shaped the emerging new American normative orders. They have looked at juridical procedures as a lens into the colonial realities

1 "Ordenanzas del Obispo de Michoacán Fray Marcos Ramírez de Prado", Ансм, Fondo Diocesano, Sección Gobierno, Serie Mandatos, Subserie Notificaciones, Caja 6, exp. 18, 16431645. These ordinances and Ramírez de Prado's tenure in Michoacán have been studied by Traslosheros, La reforma de la Iglesia del antiguo Michoacán, 6o-8o.

2 Prodi, Una historia de la justicia, 99-122; Duve, "Was ist >Multinormativität<?", 88-101. Heinz Mohnhaupt writes that "Competing species of norms - such as case law, legal science, customary law and privileges - should also be considered in order to be able to throw light on the status and function of legislation. In doing so we should not focus only on competition between these types of norms, but rather also of complementary points and convergences between them", in Mohnhaupt, "The Object of Interpretation", 63.

3 Good starting points to the study of Derecho Indiano are Tau Anzoátegui, Casuismo y sistema; essays in Tau Anzoátegui, El Jurista en el Nuevo Mundo; and the collection of legal historical studies in Duve and Pihlajamäki (eds.), New Horizons in Spanish Colonial Law. 
as well as to the translation of a juridical system into Spanish America. ${ }^{4}$ It has been argued that the establishment of the Spanish legal system paved the way for colonial domination. The acts of negotiation, resistance, and conformity manifested themselves explicitly in litigation processes wherein indigenous peoples voiced their complaints to the Spanish authorities, thus appeasing tumultuous intentions and preventing rebellions. ${ }^{5}$ While indigenous people litigated early on, the question of how they accessed Spanish juridical knowledge in the early post-conquest period still remains enigmatic. Certainly, close contact between native people and Spaniards catalysed the transmission of normative knowledge between both groups. Because religious men became major interlocutors between the conquered and the conqueror, it seems plausible that such an epistemological exchange occurred in the places of close contact between natives and clerics. In this essay, I show how clerics, with the help of local indigenous peoples, created, stored, and disseminated Catholic normative knowledge to the indigenous communities where they served as missionaries. While catechetical literature was a particular typology that condensed pragmatic religious normative knowledge, orality paved the way to its massive expansion.

4 For the English literature, see, for example, Borah, Justice by Insurance; Cutter, The Protector de Indios in Colonial New Mexico; Cutter, The Legal Culture of Northern New Spain; Herzog, Upholding Justice; Kellogg, Law and the Transformation of Aztec Culture, 1500-1700; Masters, "A Thousand Invisible Architects"; Owensby, Empire of Law and Indian Justice in Colonial Mexico; Premo, The Enlightenment on Trial; Premo and Yannakakis, "A Court of Sticks and Branches"; the essays in Ruiz Medrano and Kellogg (eds.), Negotiation within Domination; Yannakakis, The Art of Being In-Between; and Yannakakis and Schrader-Kniffki, "Between the 'Old Law' and the New'.

5 In her study of the transformation of Mexican culture among Nahua communities in the aftermath of conquest, Susan Kellogg shows that Spanish colonialism succeeded not just because of direct violence, germs, or technology but because of the subtleties of long-term domination behind cultural hegemonic practices like the colonial legal system that opened space for accommodation, negotiation and dialogue as part of conflict solution. See Kellogg, Law and the Transformation of Aztec Culture, 1500-1700, particularly her "Introduction"; and more recently Susan Kellogg, "Introduction - Back to the Future: Law, Politics, and Culture in Colonial Mexican Ethnohistorical Studies", in Ruiz Medrano and Kellogg (eds.), Negotiation within Domination, 1-17. Scholars such as Ranajit Guha and Vivek Chibber have pointed out that, in studying agency and resistance to the colonial order, for instance, communal violent resistance should not be taken for granted as most individuals would rather explore all possibilities - particularly through formal, legal appeals and informal complaints to authorities before risking their lives. Rather than looking at communal thriving forces, these authors showed that to subvert colonial regimes leaders of revolts have to convince individuals to take the risks when other means have failed. See Chibber, Postcolonial Theory and the Spectre of Capital, $162-163$. 
Hence, it is surprising how little attention has been devoted to the normative practices that emanated from religious authorities, especially with regard to canon law and moral theology, which were two pillars of the Spanish legal system implemented among the indigenous communities. Fray Marcos Ramírez de Prado's ordinances are but one example of regulations with exhortative power and of mandatory observance to all subjects in his bishopric that stem from clerical authorities. ${ }^{6}$ Thus, the cultural processes of Christian evangelisation seem a worthwhile aspect to pursue in search of how different normative cultures enmeshed during conquest and colonisation. While a variety of Catholic clerical groups worked in the Americas, the mendicant orders, mostly Franciscans, dominated the evangelical landscapes in the first century of Spanish colonialism, especially in Mesoamerica.

The early expansion of the religious orders in New Spain is well-known. The Franciscan friars Pedro Melgarejo, Diego de Altamirano, Johann Van den Auwera, Johann Dekkers, and Pierre de Gand (Pedro de Gante) were the first five missionaries in Mexico, soon followed by the so-called First Twelve or Twelve Apostles, directly sent by the Pope in 1524 to convert the recently conquered Aztecs. With the same aim, Dominicans arrived in 1526 and Augustinians in 1533; Jesuits came in 1572. At the same time, Catholic authorities prompted the establishment of a secular clergy in the Viceroyalty of New Spain (founded in 1535). In any case, since their arrival to Mexico in the wake of Hernán Cortés' conquest of Mexico-Tenochtitlan, Franciscan convents mushroomed throughout the 16th and 17th centuries to become the largest religious order in terms of manpower and extension in New Spain. The Franciscan evangelical programme quickly spread among native communities through the erection of convents and churches, and their administration of Indian parishes (doctrinas). Franciscans were quick to occupy an ever-expanding missionary frontier through an iterative process of turning frontier missions into Indian parishes and custodies into independent provinces - for instance, a 1626 census of the Franciscan province of Saint Peter and Saint Paul of Michoacán, established in 1565 , lists 135 friars and 33 convents and houses. Hence, in this essay I will focus on Franciscans and their ministry in central New Spain and its northern Michoacán frontiers in the 16th and first half of the 17th centuries to argue that Catholic religious orders were essential to the establishment of colonial normative systems in the Americas due to their close interaction with indigenous communities and their commitment to religious conversion. Frontier

6 One exception is Pardo, Honor and Personhood in Early Modern Mexico, who approaches pastoral and catechetical literature as normative knowledge. 
realities and the distance from centres of information and knowledge meant that religious men had to be creative in their responses to the new American realities with vast numbers of local peoples to be converted and less evangelical resources available than in Europe (figure 9.1). ${ }^{7}$

True, the processes of acculturation were multidirectional and owe much to the evangelisation ventures wherein both missionaries and indigenous people acted as cultural brokers in defining and re-defining normative orders that stemmed not just from traditional legal systems but also from norms with deep moral significance. Studies of the evangelisation of the Americas highlight the moral dimension of the cultural transfer between the two worlds. Hence, missionaries and indigenous people engaged in "moral dialogues" in which the other's moral concepts were casted within one's own cultural framework and, subsequently, cultural barriers dragged the translation of moral norms from Catholicism into indigenous cultures. As part of these practices, new rituals had to be introduced and behaviours had to be guided. ${ }^{8}$ It is also well-known that the Spanish conquest of America wrought havoc to indigenous societies: war, violence, disease. Because Catholic missionaries brought a sense of entitlement and absolute truth, they destroyed elements of local cultures perceived as evil. While it is true that the creation and application of religious normativities among native peoples happened in the midst of a demographic crisis of immense proportions that ravaged the lives of those who endured it, at the same time, however, through the transmission of knowledge, Catholic missionaries gave indigenous peoples the means to engage with the new colonial legal structure. ${ }^{9}$

This chapter gives particular importance to the application of codes of conduct and modes of behavioural control at the community level that stemmed from Franciscan religious men and their knowledge of canon law and moral theology. In the context of Catholic evangelism in early contact situations, I contend that Franciscans (although this might further apply to the other mendicant orders who evangelised in Mexico: Dominicans, Augustinians, and Jesuits), in conjunction with local indigenous peoples, actively participated in creating and applying a religious normative order that, by relying on moral theology, catechetical and pastoral literature (what we call pragmatic normative

7 The 1626 Census of the province of Michoacán is in AHFM, Fondo Provincia, Sección Gobierno, Caja 1, Libro de Becerro 1. The process of Franciscan expansion throughout New Spain in the 16th century is well explained in Ricard, The Spiritual Conquest of Mexico; and LópezVelarde López, Expansión geográfica franciscana.

8 Burkhart, The Slippery Earth; Lockhart, "Double Mistaken Identity"; Schwaller, "Conversion, Engagement, and Extirpation"; Yannakakis, "Beyond Jurisdictions".

9 One scholar has argued that indigenous people were born to die, see Cook, Born to Die. 
First 10 Franciscan Missions in Mexico and Final Distribution
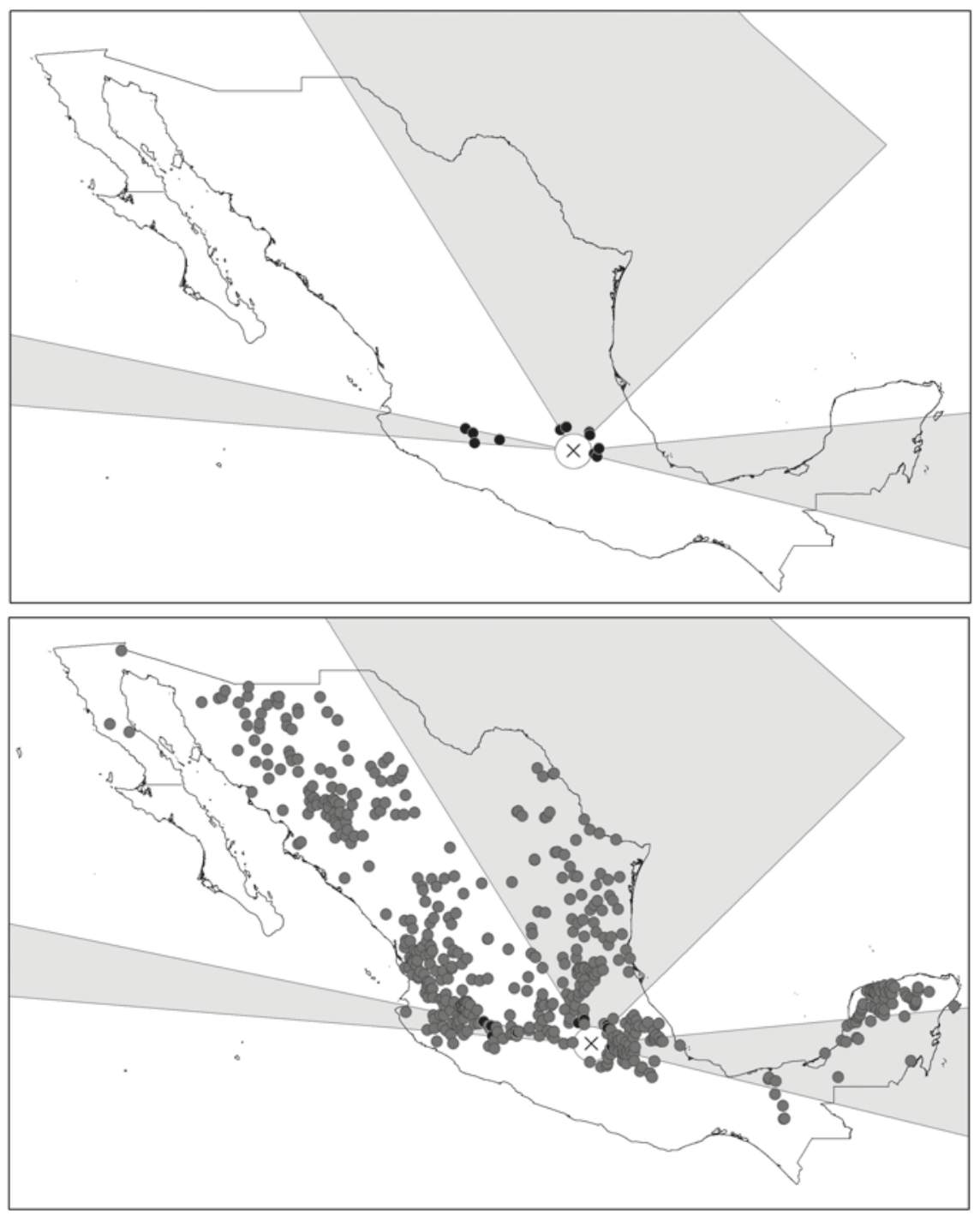

- Franciscan mission 40 miles buffer around Mexico D.F.

FIGURE 9.1 Map of Franciscan initial conventual and missionary expansion from the first 10 missions outside of Mexico City (see the western direction in Michoacán) and final distribution of doctrinas and missions in Mexico, 1520s-1810s SOURCE: MARIA WALDINGER, "THE LONG-RUN EFFECTS OF MISSIONARY ORDERS IN MEXICO", JOURNAL OF DEVELOPMENT ECONOMICS 127 (2017), 370 
literature), indigenous practices, and orality, sought to convert native people to Christianity and desensitise them towards the Spanish culture, ultimately shaping Spanish domination over the Americas. Franciscan scholars and their indigenous intellectual partners wrote day-to-day confessional writings, pamphlets, sermons, and catechisms along sophisticated treatises that, as this book shows, became functional and adaptable to the new colonial settings, particularly in remote areas with limited Spanish government in the context of the early modern Spanish empire. Not only these texts with a theological background circulated in printed and manuscript format throughout the Americas, but, as canonist Osvaldo Moutin points out, "moral theology should be considered a legal source. In many aspects of political and daily life, it will be a seminal factor. Thus, there is no lack of norms for the treatment of Indians, family life, commerce, to mention only some aspects". ${ }^{10}$ One aim is henceforth to take a fresh approach to some known catechisms, sermons, and pastoral texts from a normative, juridical perspective while exploring how religious normative knowledge was created, stored, and disseminated in New Spain.

There is a normative substratum behind religious conversion, the central focus of the Catholic missionaries. This explicit connection between conversion and normativities becomes more apparent when approaching religious conversion as a process with epistemological as well as behavioural foundations - rather than the fulfilment of rites of passage and devotions such as baptism or the Via Crucis. Religious conversion implies a worldview shift and the cultural metabolism of "basic presuppositions upon which both self and others are understood". ${ }^{11}$ It refers to the acquisition of certain knowledge as much as to

10 For an overview that approaches the genre of pragmatic normative literature from the perspectives of canon law and moral theology and its relevance to the construction of normative orders in early Ibero-America, see Thomas Duve (Chapter 1) in this volume. On the entanglement between moral theology and Western legal culture, see Prodi, Una historia de la justicia; Decock, Theologians and Contract Law; Duve, "Catequesis y Derecho Canónico”; and Moutin, Legislar en la América hispánica en la temprana edad moderna, quote is on p. 4 (my own translation). A pioneer work in pointing out that the legal culture in the Western tradition had deep roots in ecclesiastical law and moral theology, is Berman, Law and Revolution. For a recent reappraisal of Berman's work, see the Forum essays in Rechtsgeschichte - Legal History 21 (2013).

11 Buckser (ed.), The Anthropology of Religious Conversion, xi. For the following, see Rex Galindo, To Sin No More; and Rex Galindo, "Primero hombres, luego cristianos". 
a change in a person's conduct. Franciscan missionaries understood religious conversion as a metamorphosis within and without one's faith explicitly related to human behaviour. In other words, religious conversion implies a moral transformation, a change in a person's way of life that, moreover, is not linear because human nature is prone to sin and, hence, relapse prevents conversion from being complete. Religious conversion thereby implicitly comprises a cultural mutation (and adaptation) which could be voluntary but also coerced under the guidance of those who claim to possess the knowledge.

There is always a punitive factor in the conversion process, since those who convert receive the postmortem reward of eternal salvation and those who fail are condemned and punished to eternal suffering. ${ }^{12}$ As early modern people knew, the Christian God's punishment was not a rhetorical tool but a taunting reality. Moreover, in the earthly interregnum awaiting the celestial or infernal outcome, the blurred line that separated ecclesiastical from civil jurisdiction in the early modern period manifested vigorously when sinful conducts received spiritual as well as physical chastisement. This theology of fulfilment and chastisement translated to the Americas. For instance, the ordinances for Nahua confraternities Fray Alonso de Molina wrote in Nahuatl (1552) are but one example of the exhortative nature of religious normative texts. Owing to the expansion of the Franciscan missionary scaffold throughout New Spain, Molina's statutes were written as a model for other confraternities in Franciscan hospitals for indigenous peoples in central Mexico. Extending divine punishment of "sinners, idolaters and the haughty and arrogant", to the earthly world, the ordinances admonished those who failed to follow them and prescribed whippings for recidivists. In extreme cases, civil and clerical juridical branches granted justice to what were considered abominable sins that deserve the capital punishment. ${ }^{13}$

It should not be surprising that in an early modern Hispanic world of embroiled civil and ecclesiastical normativities, for those under Franciscan guardianship, moral theology provided the normative arena, setting the norms for the direction of customs; thus, it is considered a fundamental instrument to guide Catholics' behaviour. It focuses on the discussion and establishment of the individual's moral obligations within the framework of the Christian

12 See, for instance, Aquinas, Summa Theologice, 3rd Part, Question 86, Article 1: "Therefore we must say simply that, in this life, every sin can be blotted out by true Penance".

13 Nahua Confraternities, ed. Sell, 2, 99. See also Schwaller, "Constitution of the Cofradía". For cases of sodomy punished with death in colonial Peru and the application of entangled civil and ecclesiastical legal cultures in such cases, see Molina, Cuando amar era pecado. 
God's revelation. ${ }^{14}$ Within this context, in his 1643 Chronicle of the Franciscan Province of Michoacán, Fray Alonso de la Rea praised the work of his fellow Franciscan brothers among the native communities of Michoacán, a region to the west of the capital Mexico-Tenochitlán. For de la Rea, the conversion process had a clear beginning and an end. It promised the freedom of Christianity substituting the yoke of servitude of gentiles. Religion brought the law of Christ - "our law" wrote the friar - introducing native peoples into what he viewed as the true religion while condemning the false sects - namely, native American religions. Following this reasoning, friars were "legislators" who introduced the P'urépechas, indigenous people in Michoacán, to "the political and social life" through "establishing towns and the laws of policia", that is, a good quotidian order that regulated daily lives. ${ }^{15}$ This was more than a rhetorical statement. Since religious conversion had conduct connotations, de la Rea's assertion showcases Franciscan involvement in the setting of normative orders during their evangelical ministry among native peoples. Hence, their pastoral texts, aiming at conversion, maintained a normative stature in Franciscanindigenous relations. ${ }^{16}$

\section{$3 \quad$ Producing and Storing Religious Normative Knowledge}

Clerics produced a good amount of religious texts in America in the colonial period. Scholars have already pointed out that books, both in printed and manuscript versions, circulated widely in the 16 th and 17 th century Hispanic world. ${ }^{17}$ In Mexico, the majority of the printed material consisted of religious texts which aimed at conversion. Besides imported books, early on, local presses also produced books in the Americas. In 1538, Emperor Charles V granted

14 The legal mandate of moral theology was not lost in the early 2oth century Catholic Encyclopaedia, which included an entry pointing towards "the rule, or norm, of the moral order, human actions as such, their harmony or disharmony with the laws of the moral order, their consequences, the Divine aids for their right performance". In other words, "as jurisprudence must enable the future judge and lawyer to administer justice in individual cases, so must moral theology enable the spiritual director or confessor to decide matters of conscience in varied cases of everyday life". See Lehmkuhl, "Moral Theology".

15 Rea, Crónica de la Orden de N. Seráfico P.S. Francisco, 90-91, 105.

16 Normative orders, whether consensual or imposed, are sets of common norms that define human conduct. Normative orders result from processes of creation, storage, adaptation, legitimisation, and standardisation of norms, that have compelling as well as orderliness natures. See Thomas Duve (Chapter 1) in this volume and MacCormick, Institutions of Law, 11-20.

See Otto Danwerth (Chapter 3) in this volume. 
printer Juan Cromberger permission to publish a catechism in P'urépecha in Sevilla after Bishop Vasco de Quiroga's request. Juan Cromberger soon moved the press to Mexico City, where the first American book, not surprisingly a catechism in Nahuatl, was printed in $1539 .{ }^{18}$ Throughout the colonial period, friars and native people wrote extensively in local indigenous languages, predominantly Nahuatl, the lingua franca in central Mexico, but also in P'urépecha and Matlazinga, languages of Michoacán, Chontal Maya, and Otomí to name a few. In his study of religious texts written in Maya and Nahuatl languages, Mark Christensen points out that we should not take for granted that all pastoral literature in indigenous languages was the result of intensive cooperation of clerics and Indians. To be sure, printed texts adhered to this interethnic collaboration under the guidance of the religious men. However, some of the unpublished works that circulated in indigenous languages were the sole production of native people, with perhaps slight clerical guidance. Of course, other religious texts were written in Spanish and to a lesser degree in Latin. In terms of their functionality, I would like to distinguish between texts written to train other specialists or to be read by learned readers, particularly confession manuals and theological treatises, and those written to entice a non-erudite audience, particularly catechisms or doctrinal pamphlets, sermons, and speeches (pláticas). There is a good amount of scholarly work that shows how these latter pragmatic texts - those with a pastoral and catechetical character - were produced, circulated, and kept in 16 th century Mexico. ${ }^{19}$

My own research on inventories of Franciscan conventual libraries in Mexico shows that Franciscan monasteries had copies of pragmatic religious literature in their stacks, such as Martín de Azpilcueta's books - including his bestseller Manual for confessors and penitents - as well as bilingual catechisms and dictionaries in indigenous languages. Friars relied on epitomised works such as Azpilcueta's to develop their own pragmatic scholarship. ${ }^{20}$ These

18 AGI, Indiferente, 1962, L.6, fols. 127r-V and AGI, Indiferente, 1962, L.6, fol. 128. See also Burkhart, The Slippery Earth, 20.

19 Christensen, Nahua and Maya Catholicisms, chapter 2. For Nahuatl as the lingua franca of central Mexico, see the articles in Schwaller (ed.), A Language of Empire, a Quotidian Tongue. For a bibliographical study of catechisms published in America in the 16th century, see Resines Llorente, Catecismos americanos del siglo XVI, 2 vols. In his contribution of the present book, José Luis Egío (Chapter 7) shows how under bishop Juan de Zumárraga's ecclesiastical authority, pragmatic catechetical literature was produced in the 153 os and 1540 os in New Spain in the context of anti-Protestant and anti-Erasmian politics in Europe before the Council of Trent $\left(1545^{-1563}\right)$.

20 For the phenomenon of epitomisation, see Christoph Meyer (Chapter 2) in this volume. For Martín de Azpilcueta, see Manuela Bragagnolo (Chapter 6) in this volume. 
inventories are not exhaustive in their bibliographical information, as they commonly list author's last names and title keywords but make no reference to year of publication nor edition. For instance, inventories from the Franciscan convent of Tula - 120 kilometres north of Mexico City - cover the period between 1602 and the late 1620 . According to these inventories, this library was well provided with material necessary for the conversion of native peoples, mostly Otomí and Nahua speakers. The library held some summae and compendia of Martín de Azpilcueta's works as well as his confession manual, including a Latin edition. Preaching and praying stood out in the stacks, where one could find books of sermons by Dominican Fray Vicente Ferrer (1350-1419) and Franciscan Fray Antonio de Padua (c. 1195-1231), or some of Dominican Fray Luis de Granada's (1504-1588) works on prayers and meditation. The inventory lists bilingual dictionaries in Nahuatl and Spanish as well as Franciscan Fray Juan Bautista de Viseo's book of sermons (which must have been added in 1608) and Fray Alonso de Molina's bestselling confessionary (added in 1611). The library also kept some unidentified manuscripts: two cartapacios or binders of unknown topics and seven binders in Otomí language, described as treatises and miscellanea. ${ }^{21}$

General inspections of Franciscan convents conducted in the 166os in central Mexico also show the bibliographic content of other Franciscan libraries. For instance, the conventual library of Santa María de Atzompan in the current-day town of Ozumba, east of Mexico City, kept two bestsellers in moral theology and confession manuals: Father Antonino Diana's (1585-1663) Summa and Compendium (1646) and Franciscan Fray Manuel Rodríguez's (15461613) Explanation of the Bula de la Santa Cruzada (1589). In his study of confession manuals in the early-modern Hispanic world, historian Antonio González Polvillo cites these books, along with Martín de Azpilcueta's works among the most circulated books across the Atlantic in the 16th and first half of the 17th centuries. ${ }^{22}$ The convent of Tepeji del Río, 100 kilometres north of Mexico City, listed a trilingual manuscript manual in Otomí, Nahuatl, and Spanish, a manuscript dictionary of Nahuatl and Spanish, a binder with some cases of conscience, as well as manuscript sermons. ${ }^{23}$ Overall, conventual libraries kept

21 BNAH, Fondo Franciscano, vol. 45, Inventarios y memorias del Convento de Tula, passim.

22 BNAH, Fondo Franciscano, vol. 36, Convent of Santa María of Atzompan, 25 January 1661, fols. 22r-v, 51v. Fray Alonso Bravo conducted the inspection. "están cabales los sesenta y tres libros de q.e se compone". For best-selling manuals of confession and moral theology in the Hispanic World, see González Polvillo, Análisis y repertorio de los tratados y manuales. BNAH, Fondo Franciscano, vol. 40, fols. 44-48. 
Martín de Azpilcueta's various editions of his confession handbook and compendia, Fray Alonso de Molina's and Fray Juan Bautista de Viseo's confession handbooks in Nahuatl, Fray Juan Bautista de Viseo's book of sermons in Nahuatl, other printed books of sermons, bilingual dictionaries, as well as manuscript texts: mostly sermons in Nahuatl, Spanish, and even Latin. ${ }^{24}$ It should be noted that these inventories of manuscript and printed books do not account for those binders of manuscript texts and printed books kept by individual friars in their cells and those which might have just disappeared.

The bibliographical richness of Franciscan libraries envisages the variety of moral topics discussed and the strategies used during the Franciscan evangelical programme in New Spain. An interesting example emerges from a little-known manuscript in Latin and Spanish titled "Handbook in which many things are noted which are necessary for the priests' quotidian ministry". Composed by Fray Juan de la Concepción in 1597, this handwritten book of 62 sheets compiled an array of sources to help friars deal with practical cases confronted in their ministry such as polygamy, homicides, the intrusion of women into the monasteries, blasphemy, abortions, and the administration of the sacraments. Fray Juan de la Concepción mostly relied on the works of the abovementioned Fray Manuel Rodríguez, a Portuguese Franciscan who wrote extensively on moral cases, and on Martín de Azpilcueta, whom he referred to as Navarro. Texts like de la Concepción's added practical responses by veteran missionaries to real problems the religious confronted in their daily contact with New Spain's diverse communities, including doctrinas de indios and missions on the frontiers of the Spanish empire. Serve as an example of the compiler's pragmatism but also the normative nature of these texts, the inclusion of French Franciscan jurist and missionary Fray Juan Focher's brief answers to some practical cases that religious men faced in their daily ministry. It should be noted that Focher, who died in Mexico City in 1572, was a juridical and theological authority in New Spain when Fray Juan de la Concepción compiled his text in the late 16th century. The French missionary extracted his responses from a variety of sources that ranged from the Council of Trent, Paul's letters to the Corinthians, and various papal bulls, to the opinions of the theologians Thomas Aquinas (1225-1274) and John Duns Scotus (1266-1308). The questionnaire consisted of six questions that focus on controversial topics such as the jurisdictional conflicts in the administration of sacraments between regular and secular clergies, redemption of sins among indigenous

24 See other library inventories in the same volume 40 and in BNAH, Fondo Franciscano, vol. 36 . 
recidivists, Indian marriages, and potential disputes among the missionaries themselves. Friars could conduct marriages of mestizos, blacks and Spaniards within their convents, Focher admitted, but not in other jurisdictions during their visitations, following unnamed papal bulls that had hampered mendicant privileges in Mexico. He further supported that at least in confession, Spaniards and indigenous people should be dispensed alike in cases such as incest if it had been committed with a wife's relative. ${ }^{25}$

The sense of social and moral reform that missionaries wanted to imprint on Catholics and non-Christians alike can be recognised from the confession manuals that proliferated during the 16 th century. From a viewpoint of conversion, one function of confession manuals was to distil the religious normativities that missionaries disseminated to Catholics and non-Catholics in the early modern period. The social disciplining ethos of the sacrament of penance has been the focus of various studies in recent decades. A general premise has been that confession and preaching were vehicles to instigate social control and to impose an ecclesiastical normative order aimed at changing people's behaviours. ${ }^{26}$ Indeed, this normative pattern behind confession translated to Spanish America. For example, a look at the only confession handbooks published in an indigenous language in the 16th century unveils some of the normative knowledge friars sought to transmit to their Indian parishioners. Fray Alonso de Molina's bilingual confession manual in Nahuatl and Spanish, a bestseller in its own right, went through three editions: $1565,1569,1578$. The structure of this book is typical and similar to a Christian catechism that he had previously drafted in 1546: the 10 Commandments, the Catholic Church Commandments, Holy Communion, the 7 mortal sins, 14 corporal and spiritual works of mercy, the 5 senses (sight, hearing, taste, smell, and touch), and the virtues. Fray Alonso de Molina's text illustrates the practical concerns priests faced in their daily ministry. For instance, in his lengthy explanation of the 7 th commandment "thou shall not steal", he is concerned with the fairness of Indian labour conditions and tribute collection with a clear hierarchical distinction between the macehuales (Indian commoners or peasants) and caciques (Indian leaders, elites). That caciques should be asked by their confessors how they administered the tributes unveils the fluid structures of power in Spanish colonial society. Questions dealt with tax mismanagement, fundamentally unfair increases and diversion of taxes to third parties, the theft of tributes, and irregularities in the distribution of labour to distant mining centres or in

25 BNM, MS.308. For Fray Juan Focher's answers, see fols. 3or-34r.

26 See, for instance, Boer, The Conquest of the Soul, 46-47; and Turrini, La coscienza e le leggi. 
personal services for Spaniards, all of these recurrent problems in the colonial period that contravene royal legislation. Having lived in New Spain since his early teens, Fray Alonso de Molina displayed a familiarity with local practices and languages acquired during his upbringing and his later Franciscan work. Not uncommon with most missionaries, Fray Alonso, however, never acknowledged his tandem work with native Nahuatl-speaking scholars. ${ }^{27}$

We know of Fray Alonso and others' oblivion of Nahua contributions to the writing of pragmatic literature from one of their fellow brethren. Half a century after the publication of Molina's work, Franciscan Fray Juan Bautista de Viseo wrote a more elaborated confession handbook (1660) that addressed topics such as kinship and incest, matrimony, games and cards, fornication, the sale and drinking of pulque (a Mexican alcoholic fermented beverage). This Franciscan friar not only credited his collaboration but also acknowledged that other friars had also relied on local knowledge to write their pastoral works. In the prologue to his book of sermons in Nahuatl published in 16o6, Bautista de Viseo appreciated the help of his Mexican aides, who had been educated at the Franciscan College of Tlatelolco. It seems as if Mexican Hernando de Ribas - versed in Nahuatl, Latin, and Spanish and an instructor of Nahuatl, who helped various Franciscan missionaries like Fray Alonso de Molina and Fray Joan de Gaona to compose their bilingual works - particularly contributed to Bautista de Viseo's texts. He further praised the support of Joan Berardo, Diego Adriano, Francisco Bautista de Contreras, Esteban Bravo, the famous Antonio Valeriano, and Agustín de la Fuente. Interestingly enough, Bautista de Viseo lists his Mexican collaborators before he owes his intellectual debt to his Franciscan brethren. ${ }^{28}$

Certainly, instead of approaching indoctrination as a unidirectional process, Catholic evangelism became a give and take process with a bi-directional

27 Molina, Confesionario Mayor, "Acerca del septimo mandamiento de Dios", 35-45. His 1546 Doctrina Christiana included basic Christian doctrinal prayers such as explanation of the sign of the cross and its prayer, the Our Father prayer, the Hail Mary, the creed, Salve Regina, the Decalogue, the 5 commandments of the church, the 7 sacraments, 14 articles of the Catholic faith ( 7 over the blessed divinity of God and 7 over the holy humanity of Jesus), 14 corporal and spiritual works of mercy, general confession, the Eucharist, and the act of contrition; see Molina, Doctrina Christiana breve traduzida en lengua Mexicana (1546), 34-61. Other catechisms added mortal sins and the theological and cardinal virtues to basic Catholic knowledge. Catechetical works published in Europe and America included these basic teachings.

28 Bautista Viseo, A Iesu Christo S.N. ofrece este Sermonario en lengua Mexicana, Prólogo. See also Fray Juan Bautista de Viseo, Advertencias para los confesores de los naturales, 16oo, 2 vols. For a new edition of the first book with an introductory study of the author and his work, see Murillo Gallegos (ed.), Fray Juan Bautista de Viseo. 
flux. Not only does conversion imply an active role on the part of the converted as much as of the missionary, but also indigenous interpreters and intellectuals played a key role in transforming the message for wide American audiences and thus were crucial in indoctrinating the American populations. The production of Indigenous-language texts was the result of joint-research projects between the friars and local leaders. The best-known example is the co-operation between Franciscan Fray Bernardino de Sahagún and his indigenous collaborators. Sahagún had arrived in Mexico in 1530, where he pursued a long missionary career until his death in 1590. For many years, in the Franciscan College of Tlatelolco (then outside Mexico City), he trained Mexican scholars such as the abovementioned Antonio Valeriano as well as Alonso Begerano, Martín Jacobita, and Andrés Leonardo, who collaborated with the Spanish friars to compose their pastoral literature. Through teamwork, friars and indigenous advisers worked together to produce Christian catechisms and other pastoral texts that contained basic Christian doctrinal prayers. These texts list a series of mandatory religious rituals to be performed regularly. In all, Nahuas had been advising Franciscan missionaries in their writing of pragmatic literature pivotal to the introduction of religious normative knowledge with moral significance.

Other works explicitly aimed at direct catechetical indoctrination. Tactics varied. For instance, friars like Fray Maturino Gilberti in Michoacán used the scholastic dialogue between a master and a student as a method to catechise P'urépecha speakers. In Gilberti's 1559 Diálogo de Doctrina Christiana a casual encounter turns into a teaching process. His dialectical pattern echoed other diálogos de doctrina cristiana, such as the one by Juan de Valdés (14991541) published in 1529, who utilises a conversation among the archbishop of Granada, a priest, and a parishioner. As Fray Maturino Gilberti points out in his prologue to his Diálogo de Doctrina Christiana: "It is about what the Christian has to know, believe, do, desire, and hate. The disciple asks the Master".29 This method reveals a hierarchical flow of knowledge from its possessor (the teacher, the friar) to its receptor (the student) or disciple (the Indian). The disciple is as eager to learn as the master is to teach and correct. Through a Q\&A dialectical arrangement, the teacher clarifies Christian concepts whilst applying them to the student's quotidian practices. Ironically, both Valdés and Gilberti were persecuted by the Inquisition. As Moisés Franco Mendoza

29 Title page of Maturino Gilberti's Diálogo de Doctrina Christiana (1559): “Trata de lo que ha de saber, creer, hazer, dessear, y aborrecer, el Christiano. Va preguntando el discipulo al Maestro". (my own translation). 
points out in his study of Gilberti's P'urépecha corpus, Gilberti proposes a pedagogical model of catechetical implementation based on Christian doctrine through local cultural and linguistic knowledge. He deploys a normative praxis embedded in the teaching of moral precepts that normalize and guide the lives of Christians and potential converts. The teacher is not a mere vehicle of memorised information, he wants to transmit understanding to the Christian normative order. Gilberti like other religious men, might have also worked closely with local people to polish his writing and convey his message in convenient ways. ${ }^{30}$

These indigenous intellectuals, working together with Franciscan missionaries, shared their knowledge in order to bring innovative changes to their communities. As indoctrinators, the thoughts, motives, and intentions of native scholars owed much to the context in which they lived: this included not only their own cultures and institutions, but also those of the new regime that the Spaniards - including the Franciscan missionaries - aimed to implement. In the context of Spanish colonialism wherein actors operate, native people could, and, in many cases, were forced to, innovate the rules that governed their lives. Following other studies that highlight native political preeminence within their own communities under European colonial rule, a similar assertion could be pointed out for the relevance of indigenous legal and theological scholarship in the implementation of a colonial normative order. Certainly, power asymmetries appear, particularly at the macro level of Spanish colonialism in the Americas. But the daily life that involves a deeper knowledge of the internal structures of each community might reveal the way in which a few Catholic missionaries had to deal with communities of dozens, if not hundreds, of Indians. Not only were native scholars "knowledgeable", they were also "enabled" even in the midst of colonial asymmetries. ${ }^{31}$ Normative knowledge was transferred through various mechanisms in the early modern period. Besides the dissemination of written texts, communication techniques also included other mass media typologies that had also proved effective in Europe and were transferred to the Americas. I am particularly interested in studying oratory techniques as a means of application of normative knowledge.

30 For Fray Maturino Giberti's work, see Franco Mendoza, Eráxamakua, 31-32, 109-114. For Juan de Valdés, see Valdés, Diálogos de Doctrina Cristiana.

31 I have discussed these issues in further detail in Rex Galindo, Kalfelis and Nomey, "Agency and Asymmetries", 293-327. For native political pre-eminence in another colonial settings, see, for instance, Hackel, "The Staff of Leadership". 
The creation of a juridical system in New Spain mirrored the juxtaposition of oral and written communication traditions with rituals and symbols in the formation of a medieval legal corpus. The works of legal historians such as Gerhard Dilcher illustrate how even in political associations without strong, centralised state structures, conflict regulation rested on undifferentiated oral and written traditions that set the medieval normative orders. ${ }^{32}$ Orality, not just in the juridical praxis in court, but as a backbone of jurisprudence and customs translated to Spanish America in the early modern period. In a religious context, oral communication took the form of confession, preaching, and theatrical performances. In fact, confession manuals, theatrical plays, and preaching material attest to the multiple dimensions of the Franciscan evangelical programme in New Spain. This section focuses on the role preaching played in the dissemination of religious normative knowledge.

Through preaching, clerics shaped religious beliefs and set procedures to convey moral, social, and political virtues and loath vices. Even if in early modern America and Europe religious knowledge was distributed through the written word, it was through preaching that knowledge was received. Comparing the power of orality with written texts in his study of English preachers and their listeners in the late 16th and early 17th centuries, historian Arnold Hunt warns us that the written word alone could not transform ordinary peoples' lives, "because it lacked the converting power of the spoken voice". ${ }^{33}$ In a period when literacy rates were low, the spoken and visual words were the most important means of mass communication. Religious normative knowledge was produced and applied at two levels: among literate people who wrote and/ or read pragmatic texts and among illiterate people who heard, saw, and talked about the subsequent religious normative message. As art historian Samuel Y. Edgerton has shown, to appeal to the senses and convert indigenous peoples, oral skills merged with a visual apparatus produced by local indigenous artisans. Thus, even if ephemeral, preaching was still the most powerful tool to convey messages to wide audiences. It was in a sense the mass media coverage of the early modern period. Thus, in studying preaching, one needs to keep in mind not only the preacher and his message (the text) but the audience, the temporal and spatial context, the language(s), and the reactions. Because of the profound oral traditions on both sides of the Atlantic, preaching became a

32 See, for instance, Dilcher, Normen zwischen Oralität und Schriftkultur.
33 Hunt, The Art of Preaching, 10. 
major means in the transmission of religious norms in 16th- and 17th- century Mexico. ${ }^{34}$

By highlighting the importance of oral traditions in both European and American cultures we may better comprehend the spread and implementation of religious normative knowledge in 16th- and 17th-century Mexico. Orality was a central aspect of the religious life as well as the most important means to convey norms and rules to the general population in Europe. Confession and preaching, major methods to transmit normative ecclesiastical knowledge, owed much to the medieval oral traditions. Franciscan missionaries were above all communicators of the Christian doctrine, who, through an oratory 'science' or ars praedicandi, infused their own moral and social codes with the objective of changing their listeners' ways of life. Early on after their arrival in Mexico City in the 1520s, Franciscans ascended the pulpits and temporary stages in plazas, streets, and roads in villages and hamlets in order to introduce their own views over religious conversion and eternal salvation through crafted discourses that reflected intense preparation and meditation. ${ }^{35}$ The content of the message and the rhetoric were essential for reaching their audience. Moreover, to entice non-Catholics and Catholics alike to their conversion, friars exhibited a cornucopia of visual effects attached to their verbal message. Missionaries spent long hours in their conventual libraries preparing the content and eloquence of their preaching by reading handwritten and published manuals, sermons, cases of conscience, and other pragmatic texts. These texts

34 I have found the work of the "Italian Voices" Research group at the University of Leeds particularly helpful in understanding the interconnectivities between preaching, oral cultures, orality, and written texts; see, for instance, Dall'Aglio, "Voices under trial"; and the articles in Dall'Aglio, Degl'Innocenti, Richardson, Rospocher and Sbordoni (eds.), Oral Culture in Early Modern Italy. I thank Manuela Bragagnolo for these references. Missionaries and local artisans conceptualized architectural designs such as open chapels, paintings, and sculptures to operate in conjunction with the spoken word to appeal to indigenous peoples to their conversion, and hence, to the spread of a colonial normative order with ecclesiastical principles in Spanish America, Edgerton, Theaters of Conversion.

35 See, for instance, Carta al emperador por un grupo de franciscanos, entre ellos Motolinia, Cuautitlán, 17 November, 1532, Archivo Histórico Nacional, Madrid, Diversos, no. 14, published in Motolina, Epistolario (1526-1555), ed. Gómez Canedo, 92. This letter was signed by Fray Martín de Valencia, custodio, Fray Ildefonso de Herrera, guardián, Fray Martín de Jesús, guardián, Fray Juan de Padilla, guardián, Fray Antonio Civitatensis, guardián, Fray Francisco Jiménez, Fray Toribio Motolinía, Fray Alonso de Guadalupe, Fray Francisco del Álamo, and Fray Arnaldo de Bazatzio. An almost identical content in Carta al emperador por un grupo de franciscanos, entre ellos Motolinia, Tehuantepec, 18 January 1533, Archivo Histórico Nacional, Madrid, Diversos, no. 16, published in Motolina, Epistolario (1526-1555), ed. Gómez Canedo, 100. 
had pedagogic purposes for the listeners as much as for the friars themselves and constituted textbooks for the training of inexperienced preachers and missionaries. ${ }^{36}$ Preaching material (materias predicables) and the collection of sermonarios and pláticas held in the libraries reveal that preaching was the main method of bringing the flock to their conversion, and I argue, the means of instilling religious normative knowledge with a strong moral component. Ultimately the goal was to bring men and women to the confessional.

Since the Middle Ages, the art of religious oratory, or ars praedicandi (referring to both the craft and the genre) - homiletics as a theological discipline studied and transmitted the methods and skills of preaching. Printed or manuscript sermons and preaching guides, some written by priests and missionaries to teach future orators, circulated in Europe and crossed the Atlantic to foster evangelical ministry in America. Fray Luis de Granada (1504-1588) and Fray Martín de Velasco (c. 1621 - date of death unknown), who authored the Retórica augmentativa and arte de escribir sermones, stand out as representatives of the ars praedicandi in the early modern Hispanic world, and their work circulated amply among religious men in colonial Mexico. Friars in Mexico also showed great concern with this genre and topic. ${ }^{37}$

In the viceroyalty of New Spain, the culmination of the ars preadicandi definitely came from the hands of a Franciscan mestizo. In 1579, Fray Diego de Valadés, a veteran preacher and missionary in Mexico, published his Rhetorica Christiana in Italy, a dense volume in Latin dedicated to the art and practice of preaching. While the book was published as a handbook on preaching techniques, Valadés introduced sections on Mexican culture and the process of evangelisation, with a particular focus on the Franciscan evangelical ministry among the indigenous peoples. Following a motto rooted in the classical works on rhetoric, Fray Diego de Valadés pointed out that preaching had "to teach, to delight, and to motivate". Sermons should be intelligent and delightful, delivered by preachers with obedience. According to this ars praedicandi, preaching was an art measured in words as well as in manners. The aim of the sermon, theorists like Valadés emphasised, was to instruct listeners in the rudiments of the Catholic faith and to reform their customs. Valadés pointed out that "the preacher has to do everything in his hand to preach well". Wisdom and knowledge were prerequisites for good preachers. The message had to be poignant in order to affect parishioners' feelings. Of course, it had to be

\footnotetext{
36 Following theologian Octavio Luna, and historians Federico Palomo and Hilary Dansey Smith, among other scholars, I have discussed this issue in Rex Galindo, To Sin No More, 239-240. 
spoken in the vernacular of the listeners. Besides carefully crafting the content of their sermons, preachers also polished the aesthetics. Valadés' engraving of the preacher on the pulpit and his audience captures the dynamism of preaching (figure 9.2). To translate the basic elements of Catholic doctrine and to help with memorisation, friars instructed Indians with words but also with images. Friars also controlled the preaching spaces. In Valadés' picture, the audience sits in hierarchical and gendered order. In the first row, the indigenous judges show their varas as governors of the 'república de indios.' ${ }^{38}$

The Tlaxcalan friar gives hints at the pedagogical tools used during catechetical instruction. One of his most iconic and reproduced engravings on Franciscan activities in the New World is a representation of a conventual patio that offers readers a snapshot into the daily activities of missionaries and their catechumens. In the image, which depicts an idealised open chapel, different aspects of the evangelical agenda are orderly represented. In a composition layout centred on a group of Franciscan missionaries led by Saint Francis transporting the Catholic Church onto Mexico, the friar shows his readers the life of Mexican indigenous peoples from childhood until death under Franciscan missionary care. One can see missionaries instructing native peoples in general knowledge, teaching the Christian doctrine and the sacraments, attending to the sick, and parading the dead. At the base of the engraving, religious men administer the sacraments to the recently converted, and, at the bottom-centre, grant justice. This idealised image seems to be self-complete of a new world in which the friars fulfil their evangelical mission through the spiritual and worldly care of their flock (figure 9.3).

According to Valadés' utopian description of the activities in each Indian town, indios doctrineros prayed publicly; children learned how to speak, sing, play instruments, and write; and all attended the sermons. Notwithstanding the idealism of these reflections, oral culture pervaded the Franciscan evangelisation programme, wherein religious men exhorted and preached to

38 Valadés, Rhetorica Christiana, 24: "El predicador deber hacer todo lo posible para conseguir hablar bien". "Pues como dice San Gregorio, acepta el oficio de pregonero todo el que sube al sacerdocio para caminar gritando ante la llegada del juez que terriblemente llega". X. Del oficio del predicador: "Mas el que aspira a persuadir por medio de la palabra lo que es bueno, sin desechar ninguna de estas tres cosas, a saber, enseñar, deleitar, conmover, perore y actúe para que sea oído inteligente, gustosa y obedientemente". See pages 211-214 for the engraving of the preacher and an explanation. Preaching theorists agreed that teaching, delighting and motivating were the preachers' three essential tasks to reform their audiences' lives. See, for instance, Smith, Preaching in the Spanish Golden Age, 6o-61. For the entanglement of visual art and preaching as tools of conversion, see Edgerton, Theaters of Conversion. 


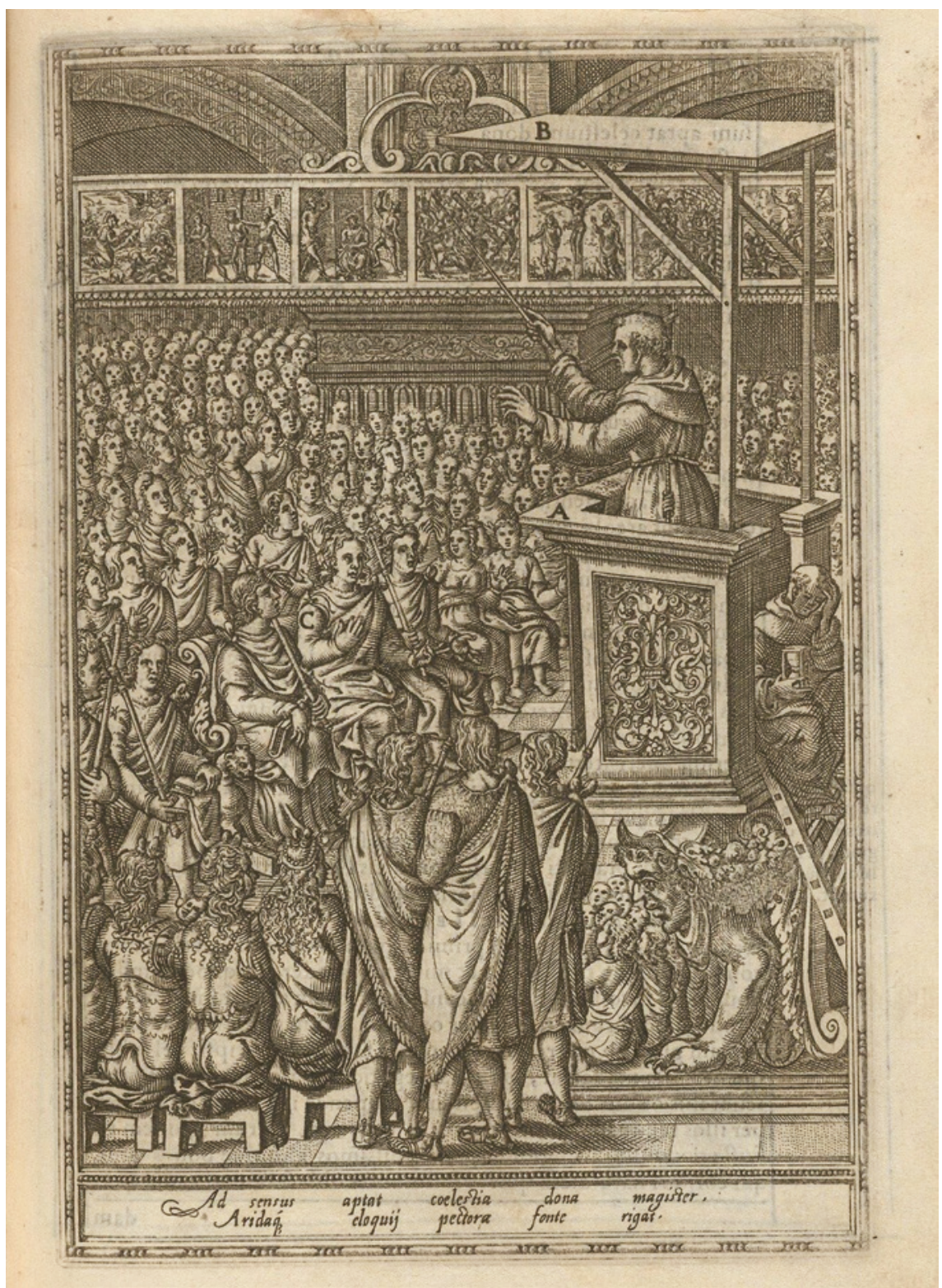

Figure 9.2 Valadés, Fray Diego de, Rhetorica Christiana, Perugia 1579, 211

SOURCE: "TYP 525.79.865, HOUGHTON LIBRARY, HARVARD UNIVERSITY" 


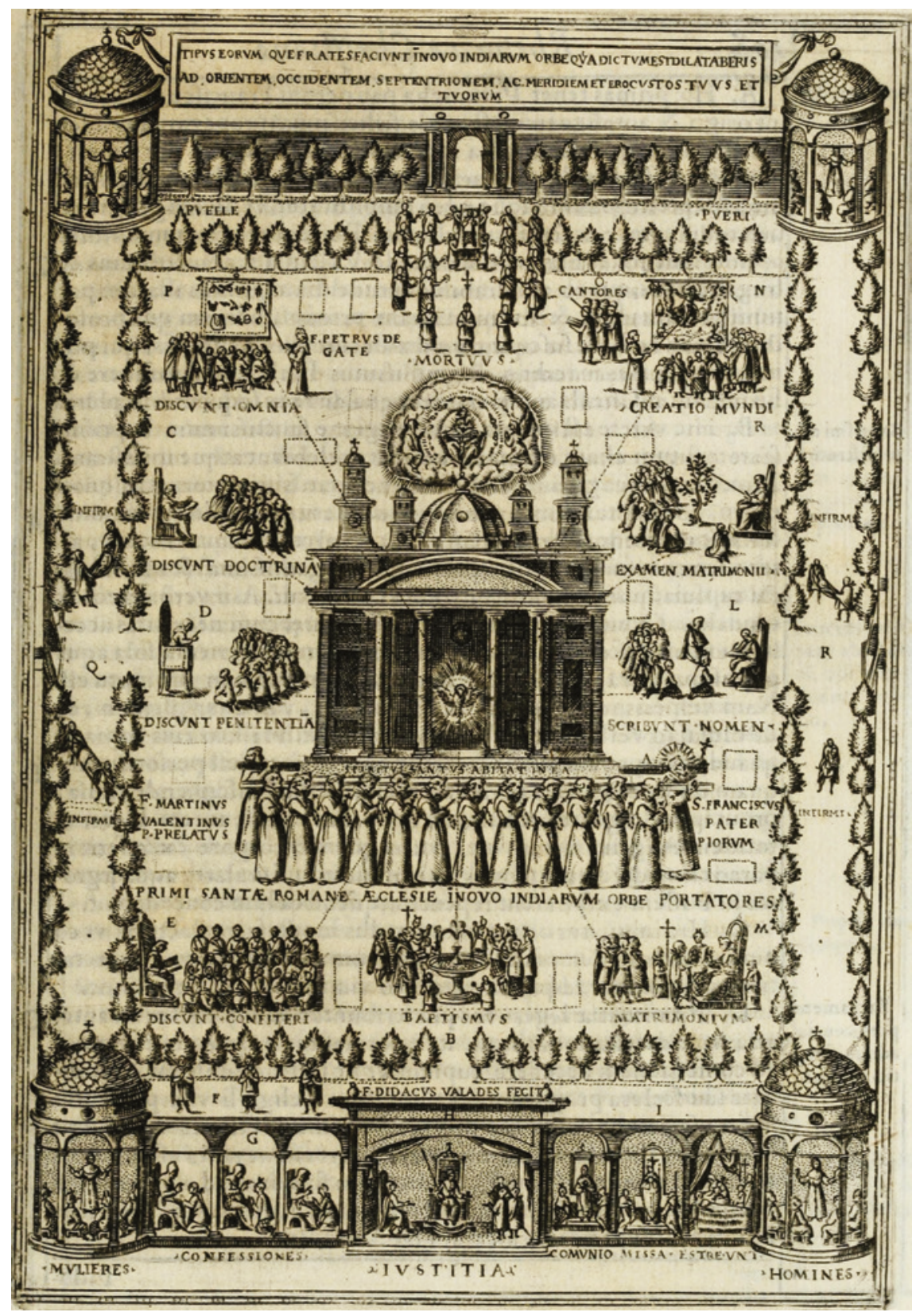

FIGURE 9.3 Valadés, Fray Diego de, Rhetorica Christiana, Perugia 1579, 107 
emphasise the dichotomy between virtues and eternal reward with sins and punishments. Missionaries became the righteous mediators of divine justice over the American peoples, where the city of God would triumph under the authority of the clerics. It was hence paramount to the missionaries to show that the new justice, which emanated for the Christian God through the Pope, the Catholic monarchy and ultimately the Franciscan missionaries, should supplant the indigenous normative system. The author pointed out that the evangelical pedagogy culminated in a Decalogue-structured questionnaire when listeners counted with "corn seeds or little stones their sins and their number" and friars showed pictures of sinners and sins to deter listeners from the path towards condemnation..$^{39}$ Even if an idealised representation, Fray Diego de Valadés' imagery did reflect upon one of various levels of multinormativy that regulated the lives of the Spanish monarch's subjects in the early modern Hispanic world, particularly those catechised by the Franciscan missionaries.

The importance of orality and preaching are ubiquitous in the writings and praxis of the missionaries as well as in native-language texts. The earliest surviving chronicle of Michoacán, written by Fray Diego Muñoz in 1585, emphasised the importance of preaching to the early missionaries of Michoacán. Muñoz's prosopographical study of missionaries highlights his brethren's ability to disseminate the spoken word. True, his words are part of the hagiographic fanfare of his time, but his chronicle (and others) underscores the centrality of orality in the transmission of (normative) knowledge. The first Franciscan missionary in Michoacán, Fray Martín de Jesús, early on "began to preach the evangelical law, and to convert and baptise large numbers of unfaithful, destroying idolatries, erecting crosses and images and teaching the Christian doctrine". Muñoz puts Martín de Jesús at the top of a preaching that ensued: "His successors left, with their entire works, flat and clear the way of preaching to us who followed them". ${ }^{40}$ And the list goes on and on to include great orators such as Fray Jacobo Daciano, Fray Maturino Gilberti, Fray Juan de Padilla, or Fray

\footnotetext{
39 Valadés, Rhetorica Christiana, 209-215.

40 Fray Diego Muñoz's manuscript "Descripción de la Provincia de los Apóstoles San Pedro y San Pablo en las Indias de la Nueva España" is in ASOFM, M.33. I have also used Atanasio López's edition of Muñoz's “Descripción de la Provincia de los Apóstoles San Pedro y San Pablo en las Indias de la Nueva España" in López, "Misiones o doctrinas de Michoacán y Jalisco", 393-394: “y comenzó a predicar la ley evangélica y convertir y baptizar grandísimo número de infieles, destruyendo la idolatría, poniendo cruces e imágenes y enseñando la doctrina cristiana"; "sus sucesores dejaron, con sus enteros trabajos, llano y desembarazado el camino de la predicación a los que les sucedimos". (my own translation).
} 
Francisco Lorenzo. ${ }^{41}$ The Nahuatl Ordinances of the confraternity of the Immaculate Conception in Mexico City, written in $155^{2}$ by Fray Alonso de Molina, were to be read out aloud to all male and female members of the confraternity on the vigil of the feast day so that its members got acquainted with such rules or were reminded of them. Various versions were handwritten probably for such occasions. They requested that the whole confraternity prayed and sang together what had previously been memorised: the Veni creator spiritus. ${ }^{42}$

Preaching guides and sermons offered the friars enough material to draft their own orations from an extensive pool of topics that included cornerstone themes of Catholic doctrine such as the Ten Commandments and spiritual devotions to the Virgin Mary in her various avocations and to the saints. Moreover, religious men also distilled preparatory information from sermons, pláticas, and references, centred on social and moral issues. In all cases, sermon authors wrote extensively about sexuality, profane spectacles, and gender relations, and to a lesser extent about socio-economic themes. Sermonarios from Mexico included a good repertoire of sermons and pláticas with a moral and social emphasis, including themes such as lewdness, bad habits, gallantry, drunkenness, dresses, dances, comedies, gender relations, and gambling. ${ }^{43}$ Missionaries carried their evangelisation material with themselves - in boxes with pragmatic literature such as compilations of sermons and catechetical works.

41 "Descripción de la Provincia de los Apóstoles San Pedro y San Pablo en las Indias de la Nueva España" in López, "Misiones o doctrinas de Michoacán y Jalisco", 396-397 (Fray Jacobo Daciano): "Veniánle los Indios de pueblos muy remotos a ver y comunicar sus trabajos, y él los consolaba y animaba con eficacísimas palabras, en lo cual tenía especial gracia". For Fray Maturini Gilberti, see "Descripción de la Provincia de los Apóstoles San Pedro y San Pablo en las Indias de la Nueva España", in López, "Misiones o doctrinas de Michoacán y Jalisco", 401. For Fray Juan de Padilla, see "Descripción de la Provincia de los Apóstoles San Pedro y San Pablo en las Indias de la Nueva España", López, "Misiones o doctrinas de Michoacán y Jalisco", 403. For Fray Francisco Lorenzo, see "Descripción de la Provincia de los Apóstoles San Pedro y San Pablo en las Indias de la Nueva España”, López, "Misiones o doctrinas de Michoacán y Jalisco", 409. Over half a century later, Fray Alonso de la Rea would also describe Muñoz's rhetorical abilities: "Su hablar era poco, pero tan sentencioso y elocuente, que hoy se guardan sus escritos como si fueran de un Justo Lipsio, así por su narración como por su letra, por ser excelente escribano". De la Rea further attests Muñoz's abilities as a moralist: "fue gran sumista, y resolvía con gran destreza los casos más difíciles que ventila la teología moral”. Rea, Crónica de la Orden de N. Seráfico P.S. Francisco, Capítulo 13, 248-249.

$42 \quad$ Nahua Confraternities, ed. Sell, 101.

43 See, for instance, George Baudot's study of Fray Bernardino de Sahagún's sermons and Fray Andrés de Olmos' writings on mortal sins in Baudot, La pugna Franciscana por México. 
The ars praedicandi also had deep roots in American cultures. In central Mexico, civil and spiritual leaders relied on their speeches and rhetorical skills to establish loyalty and spread political and spiritual instructions. Nahuas distinguished the authority of a speech from the word huehuetlatolli or "ancient wisdom, speech of the elders", and a distinct glyph. The huehuetlatolli was hence a speech of wisdom that emanated from higher authorities and thus had an intrinsic value. In Michoacán, P'urépecha leaders of all levels, from the $c a$ zonzi or king and petámuti or supreme spiritual leader to lesser governors and priests, also used the spoken word as a political tool of control. It was through speeches that leaders could have their messages, mandates and requirements be heard. Petámuti in P'urépecha means the "great speaker", and he and his priests, called curitiecha, were considered preachers in the Relación de Michoacán, and the hatapatiecha were town criers who marched and sang in front of war captives. ${ }^{44}$ The compiler of the Relación de Michoacán, Fray Jerónimo de Ayala, pointed out that his story of P'urépecha leadership owed much to local oratory traditions that stemmed from the Petámuti, who orally transmitted the official story of his kingdom to the minor priests or curitiechas to spread the narrative to his vassals. ${ }^{45}$

Spaniards were aware of these traditions. Speaking of the P'urépechas in the mid-16th century, the first bishop of Michoacán Vasco de Quiroga exclaimed "Have you heard among illiterate people such eloquent speakers?!" [“i¿Han oído ustedes, entre gente iletrada, oradores tan elocuentes?!"] Thus, when they arrived in Mexico, European preachers found people already used to giving and listening to normative religious knowledge. Friars relied on local collaborators in the conversion deeds. They elected and trained fiscales and mayordomos from the local elites to teach the Christian doctrine. In Nueva Galicia, Fray Diego Muñoz wrote that two native Franciscan donados, Lucas and Sebastián widely preached to both converted and non-Christian Indians. They even took part in missionary campaigns to New Spain's northern frontiers, where they preached to independent, non-Christian Indians. Nonetheless, the chronicler did not mention the inevitable linguistic problems that these men faced. Lucas was described as a virtuous Christian man although he was never ordained as a friar because he was an Indian. ${ }^{46}$ On the other hand, Fray Diego de Valadés,

44 For the Aztecs, see Lockhart, The Nahuas After the Conquest, 406. For Michoacán, see Alcalá, Relación de Michoacán, Tercera Parte, cap. 2: "En los cués había estos sacerdotes siguientes", 195-196.

45 Martínez Baracs, Convivencia y utopía, 87-88.

46 Franco Mendoza, Eráxamakua, 147-152. Quiroga's quote on 148. For Diego Muñoz's account on the two native Donados, see López, “Descripción de la Provincia”, 403-404. 
son of a Tlaxcalan mother and Spanish father, involved himself in catechetical and probably preaching ministry among Nahuatl- and Otomí-speaking peoples, languages that he mastered, prior to his ordination as a friar and priest. ${ }^{47}$ Sources and scholars have underlined the reliance on children, particularly the offspring of caciques, as cultural-brokers in colonial settings such as 16th century Mexico. ${ }^{48}$ The spread of religious norms was hence the result of a multiethnic and multitudinous effort.

Translating posed major challenges, though. Not only did some concepts have no corresponding terms but friars faced difficulties with the message itself. There are some studies on how concepts such as the Holy Trinity, God, Eucharist, and other Catholic concepts, were translated and explained to local communities. Particularly problematic was the explanation of the Holy Trinity in Nahuatl, to which Fray Juan Bautista de Viseo dedicated a whole section in his 1600 Advertencia para confesores de naturales. Kinship and differing definitions of incest also concerned the missionaries such as Fray Juan Bautista. In a recent study of an unpublished Nahuatl text on the Via Crucis (Stations of the Cross) written around the mid-17th century and attributed to Franciscan fray Agustín de Vetancourt, John Schwaller contrasts the differences between Vetancourt's Nahua text and other Spanish versions of the Via Crucis. One striking omission in the second station is the absence of Isaac's sacrifice in his explanation of the Passion of Christ, as it was customary to discuss a troublesome topic in the first decades after the fall of Mexico-Tenochitlan: the eradication of human sacrifice among Mexican nations. ${ }^{49}$

\section{5}

\section{Concluding Remarks}

By the mid-17th century, theologians and chroniclers who wrote on human sacrifice did so as part of a Mesoamerican past. Only as the frontier unfolded, new instances (even if imaginary) of human sacrifice among peripheral indigenous groups appeared in the sources. Fray Marcos Ramírez de Prado's 1643 ordinances composed for the Christian subjects in his bishopric of Michoacán were mute on this matter. However, some of the themes in his exhortations

\footnotetext{
47 Esteban J. Palomera, "Introducción”, in Valadés, Rhetorica Christiana, X.

48 For the use of children as cultural brokers, see "Carta al emperador por un grupo de franciscanos, entre ellos Motolinia", Cuautitlán, 17 November 1532, Archivo Histórico Nacional, Madrid, Diversos, no. 14, published in Motolina, Epistolario (1526-1555), ed. Gómez Canedo, 92.

Schwaller, "Fr. Agustín de Vetancurt".
} 
remained an open matter of implementation throughout the colonial period in Mexico. This is directly connected to my understanding of religious conversion (which is ultimately incomplete) as normative implementation.

I think that an explicit connection between religious conversion, moral theology, and normative knowledge offers a venue to address the spread and application of religious norms in colonial Spanish America. I hope to have shown that we can approach Catholic evangelism as a process of creation, propagation, and application of religious normativities that govern peoples' everyday lives in peripheral imperial milieus. As a corollary, we can assume that Catholic religious orders were essential to the establishment of colonial normative systems in the Americas due to their close interaction with indigenous communities and their commitment to religious conversion. But it has further been demonstrated that these processes of normative dissemination were not unidirectional. It was through Christian missionaries and local native aides that European normative ideas were translated to indigenous communities. In many cases, we have seen how these religious normativities were implemented through confession and preaching.

In the midst of weak state control, missionaries and their indigenous partners wrote day-to-day pragmatic confessional writings, pamphlets, sermons, and catechisms along sophisticated treatises that, we believe, became functional and adaptable to the new frontier settings. This "pragmatic normative literature" with a theological, evangelical underpinning gained ad hoc significance and functionality in remote areas with limited Spanish government in the context of the early modern Spanish empire. For instance, pragmatic literature encompassed small pastoral works that priests carried in their pockets or under their robes. This literature, with a strong moral component, served as the basis to conversion - not only of the indigenous people, the focus of my chapter - in Spanish America. I suggest that a look at library inventories and a focus on the importance of oral traditions on both sides of the Atlantic may explain the creation, collection, and spread - as uneven as it might have been - of normative religious knowledge in the 16th-century Hispanic world. Both preaching and confession played pivotal roles in the implementation of a normative order. In spite of the corrective nature of confession, ecclesiastical norms were first heard. Both cultures used rhetorical techniques filled with metaphorical symbolism, corporal gestures, and visual symbols to instigate order.

As recent research has pointed out, the process of conversion of Spanish America was incomplete at its best. Some scholars even write about the various Catholicisms that Catholic clerics brought and transmitted to native communities. Native people who received the Christian message did it in polyphonic 
and sometimes distorted ways. Native Americans adapted these multiple voices into their own cosmology to mould their local, individual Catholicism. ${ }^{50}$ This means that the implementation of ecclesiastical normative knowledge was irregular and affected indigenous communities in unpredictable ways.

\section{Acknowledgements}

I would like to thank Manuela Bragagnolo, Oracio Condorelli, Otto Danwerth, Max Deardorff, Thomas Duve, José Luis Egío, Carlos Alberto González Sánchez, Tamar Herzog, Constanza López, Osvaldo Moutin, Pedro Rueda Ramírez, and John F. Schwaller for the comments and suggestions throughout the elaboration of this essay. My particular gratitude to Thomas Duve for his support while I was a researcher at the Max-Planck-Institut für europäische Rechtsgeschichte and beyond. I am also grateful to Ana María Ruiz Marín, of the Archivo Histórico de la Provincia Franciscana de Michoacán, and the staffs of the Biblioteca Nacional de México, Museo de Antropología e Historia, Archivo Storico dell'Ordine dei Frati Minori, Museo y Archivo Histórico Casa de Morelos, and the Archivo General de Indias for their kind and diligent support in locating documents.

\section{Bibliography}

\section{Manuscripts}

Archivo General de Indias, Sevilla (AGI), Indiferente, 1962, L.6.

Archivo Histórico Provincial Franciscano de Michoacán, Celaya [México] (AHFM), Fondo Provincia, Sección Gobierno, Caja 1, Libro de Becerro 1.

Archivo Storico dell'Ordine dei Frati Minori, Roma (ASOFM), M.33.

Biblioteca Nacional de Antropología e Historia, México D.F. (вNAн), Fondo Franciscano, vols. $36,40,45$.

Biblioteca Nacional de México, México D.F. (BNM), MS.zo8.

Museo y Archivo Histórico Casa de Morelos, Morelia [México] (АнСм), Fondo Diocesano, Sección Gobierno, Serie Mandatos, Subserie Notificaciones, Caja 6, exp. 18, 1643-1645.

$5^{\circ}$ See, for instance, Christian, Local Religion in Sixteenth-Century Spain and the essays in Nesvig, Local Religion in Colonial Mexico. For the idea of multiple Catholicisms, see Christensen, Nahua and Maya Catholicisms. For the incompleteness of conversion, see Rex Galindo, To Sin No More. 


\section{Printed Sources}

Alcalá, Fray Jerónimo de, Relación de Michoacán, 1541, Madrid 2002.

Aquinas, Thomas of, Summa Theologice, trans. Fathers of the English Dominican Province, 1920 (Online edition 2017: http://www.newadvent.org/summa).

Bautista Viseo, Fray Juan, A Iesu Christo S.N. ofrece este Sermonario en lengua Mexicana, Mexico City 16o6: En casa de Diego Lopez Daualos, y a su costa.

López, Atanasio, Misionesy doctrinas de Michoacány Jalisco, in Archivo Ibero-Americano 18 (1922), 341-425.

Molina, Fray Alonso de, Confesionario Mayor, en la lengua mexicana y castellana, México 1569: En Casa de Antonio Espinosa Impressor.

Molina, Fray Alonso de, Doctrina Christiana breve traduzida en lengua Mexicana (1546), in Códice Franciscano. Siglo XVI, ed. Icazbalceta, Joaquín García, 2nd ed., México 1941. Motolina, Fray Toribio, Epistolario (1526-1555), ed. Gómez Canedo, P. Lino, México 1986. Murillo Gallegos, Verónica (ed.), Fray Juan Bautista de Viseo y sus Advertencias para los confesores de naturales, México 2014.

Nahua Confraternities in Early Colonial Mexico: The 1552 Nahuatl Ordinances of Fray Alonso de Molina, OFM, trans. Barry D. Sell, ed. Sell, Barry D. (with contributions by Larissa Taylor and Asunción Lavrin. Introduction by John F. Schwaller), Berkeley, CA 2002.

Rea, Alonso de la, Crónica de la Orden de N. Seráfico P.S. Francisco, Provincia de San Pedro y San Pablo de Mechoacan en la Nueva España (1639), México 1882.

Resines Llorente, Luis, Catecismos americanos del siglo XVI, 2 vols., Salamanca 1992.

Valadés, Diego de, Rhetorica Christiana (Perugia 1579), México 1989.

Valdés, Juan de, Diálogos de Doctrina Cristiana, Alcalá de Henares 1529.

\section{Literature}

Baudot, George, La pugna franciscana por México, México 1990.

Berman, Harold J., Law and Revolution: The Formation of the Western Legal Tradition, Cambridge, MA 1983.

Boer, Wietse de, The Conquest of the Soul: Confession, Discipline, and Public Order in Counter-Reformation Milan, Leiden 2001.

Borah, Woodrow, Justice by Insurance: The General Indian Court of Colonial Mexico and the Legal Aides of the Half-Real, Berkeley, CA 1983.

Buckser, Andrew, Stephen D. Glazier (ed.), The Anthropology of Religious Conversion, Lanham, MD 2003.

Burkhart, Louis M., The Slippery Earth: Nahua-Christian Moral Dialogue in SixteenthCentury Mexico, Tucson, AZ 1989.

Chibber, Vivek, Postcolonial Theory and the Spectre of Capital, London 2013.

Christensen, Mark Z., Nahua and Maya Catholicisms: Texts and Religion in Colonial Central Mexico and Yucatan, Stanford, CA 2013. 
Christian, William A., Local Religion in Sixteenth-Century Spain, Princeton, NJ 1981.

Cook, Noble David, Born to Die: Disease and New World Conquest, 1492-1650, Cambridge 1998.

Cutter, Charles R., The Protector de Indios in Colonial New Mexico, 1659-1821, Albuquerque, NM 1986.

Cutter, Charles R., The Legal Culture of Northern New Spain, Albuquerque, NM 1995.

Dall'Aglio, Stefano, "Voices under trial. Inquisition, abjuration, and preachers' orality in sixteenth-century Italy", in Renaissance Studies 31:1 (2017), 25-42.

Dall'Aglio, Stefano, Luca Degl'Innocenti, Brian Richardson, Massimo Rospocher and Chiara Sbordoni (eds.), Oral Culture in Early Modern Italy: Performance, Language, Religion, in The Italianist 34:3 (2014).

Decock, Wim, Theologians and Contract Law. The Moral Transformation of the Ius Commune (ca.1500-1650), Leiden 2013.

Dilcher, Gerhard, Normen zwischen Oralität und Schriftkultur: Studien zum mittelalterlichen Rechtsbegriff und zum langobardischen Recht, Köln, Weimar 2008.

Duve, Thomas, "Catequesis y Derecho Canónico entre el viejo y el nuevo mundo", in Schmidt-Riese, Roland (ed.), Catequesis y Derecho en la América colonial, Madrid 2010, 131-145.

Duve, Thomas, "Was ist >Multinormativität‘? - Einführende Bemerkungen”, in Rechtsgeschichte - Legal History 25 (2017), 88-101.

Duve, Thomas and Heikki Pihlajamäki (eds.), New Horizons in Spanish Colonial Law. Contributions to Transnational Early Modern Legal History. Frankfurt am Main 2015 (10.12946/gplh3).

Edgerton, Samuel Y., Theaters of Conversion: Religous Architecture and Indian Artisans in Colonial Mexico, Albuquerque, NM 2001.

Franco Mendoza, Moisés, Eráxamakua: Utopía de Maturino Gilberti, Zamora 2016.

González Polvillo, Antonio, Análisis y repertorio de los tratados y manuales para la confesión en el mundo hispánico (ss. XV-XVIII), Huelva 2010.

Hackel, Steven W., "The Staff of Leadership: Indian Authority in the Missions of Alta California", in The William and Mary Quarterly 54:2 (1997), 347-376.

Herzog, Tamar, Upholding Justice: Society, State, and the Penal System in Quito (16501750), Ann Arbor, MI 2004.

Hunt, Arnold, The Art of Preaching: English Preachers and their Audiences, 1590-1640, Cambridge 2010.

Kellogg, Susan, Law and the Transformation of Aztec Culture, 1500-1700, Norman, OK 1995 .

Lehmkuhl, Augustinus, "Moral Theology”, in The Catholic Encyclopedia 14 (1912) (http:// www.newadvent.org/cathen/146o1a.htm).

Lockhart, James, The Nahuas After the Conquest: A Social and Cultural History of the Indians of Central Mexico, Sixteenth Through Eighteenth Centuries, Stanford, CA 1992. 
Lockhart, James, "Double Mistaken Identity: Some Nahua Concepts in Post Conquest Guide", in Lockhart, James, Of Things of the Indies: Essays Old and New in Early Latin American History, Stanford, CA 2000, 98-119.

López-Velarde López, Benito, Expansión geográfica franciscana en el hoy Norte Central y Oriental de México, México 1964.

MacCormick, Neil, Institutions of Law: An Essay in Legal Theory, Oxford 2007.

Martínez Baracs, Rodrigo, Convivencia y utopía: El gobierno indio y español de la ciudad de Mechuacan, 1521-1580, México 2005.

Masters, Adrian, "A Thousand Invisible Architects: Vassals, the Petition and Response System, and the Creation of Spanish Imperial Caste Legislation", in Hispanic American Historical Review 98:3 (2018), 377-406.

Mohnhaupt, Heinz, "The Object of Interpretation: Legislation and Competing Normative Sources of Law in Europe During the 16th to 18th Centuries", in Morigiwa, Yasutomo, Michael Stolleis and Jean-Louis Halperin (eds.), Interpretation of Law in the Age of Enlightenment. From the Rule of the King to the Rule of Law, Heidelberg 2011, 61-89.

Molina, Fernanda, Cuando amar era pecado: Sexualidad, poder e identidad entre los sodomitas coloniales (Virreinato del Perú, siglos XVI-XVII), Lima 2017.

Moutin, Osvaldo Rodolfo, Legislar en la América hispánica en la temprana edad moderna. Procesos y características de la producción de los Decretos del Tercer Concilio Provincial Mexicano (1585), Frankfurt am Main 2016.

Nesvig, Martin A., Local Religion in Colonial Mexico, Albuquerque, NM 2006.

Owensby, Brian P., Empire of Law and Indian Justice in Colonial Mexico, Stanford, CA 2008.

Pardo, Osvaldo F., Honor and Personhood in Early Modern Mexico, Ann Arbor, MI 2015.

Premo, Bianca, The Enlightenment on Trial: Ordinary Litigants and Colonialism in the Spanish Empire, New York, NY 2017.

Premo, Bianca and Yanna Yannakakis, "A Court of Sticks and Branches: Indian Jurisdiction in Colonial Mexico and Beyond", in The American Historical Review 124:1 (2019), 28-55.

Prodi, Paolo, Una historia de la justicia: De la pluralidad de fueros al dualismo moderno entre conciencia y derecho, trans. Luciano Padilla, Madrid 2008.

Rex Galindo, David, "Primero hombres, luego cristianos: Un análisis sobre la conversión forzosa en la frontera de Texas", in Colonial Latin American Historical Review 2:3 (2014), 405-432.

Rex Galindo, David, To Sin No More: Franciscans and Conversion in the Hispanic World, 1683-1830, Stanford, CA 2018.

Rex Galindo, David, Melina Kalfelis and José Luis Paz Nomey, "Agency and Asymmetries: Actors and their Access to Resources in Colonial and Developmental Setting", in Amelung, Iwo, Hartmut Leppin and Christian A. Müller (eds.), Discourses of 
Weakness and Resource Regimes: Trajectories of a New Research Program, Frankfurt am Main 2018.

Ricard, Robert, The Spiritual Conquest of Mexico: An Essay on the Apostolate and the Evangelizing Methods of the Mendicant Orders in New Spain, 1523-1572, trans. Lesley Byrd Simpson, Berkeley, CA 1966.

Ruiz Medrano, Ethelia and Susan Kellogg (eds.), Negotiation within Domination: New Spain's Indian Pueblos Confront the Spanish State, Boulder, CO 2010.

Schwaller, John F., "Constitution of the Cofradía del Santíssimo Sacramento of Tula, Hidalgo, 1570", in Estudios de Cultura Nahuatl 19 (1989), 217-244.

Schwaller, John F., "Conversion, Engagement, and Extirpation: Three Phases of the Evangelization of New Spain, 1524-1650", in Kendall, Calvin B., Oliver Nicholson, Jr. Phillips, William D. and Marguerite Ragnow (eds.), Conversion to Christianity from Late Antiquity to the Modern Age: Considering the Process in Europe, Asia, and the Americas, Minneapolis, MN 2009, 259-292.

Schwaller, John F., "Fr. Agustín de Vetancurt: The 'Via crucis en mexicano', in The Americas 74:2 (2017), 119-137.

Schwaller, Robert C. (ed.), A Language of Empire, a Quotidian Tongue: The Uses of Nahuatl in New Spain (Special issue of Ethnohistory 59:4), Durham, NC 2012.

Smith, Hilary Dansey, Preaching in the Spanish Golden Age: A Study of Some Preachers of the Reign of Philip III, Oxford 1978.

Tau Anzoátegui, Víctor, Casuismo y sistema: Indagación histórica sobre el espíritu del Derecho Indiano, Buenos Aires 1992.

Tau Anzoátegui, Víctor, El Jurista en el Nuevo Mundo. Pensamiento. Doctrina. Mentalidad, Frankfurt am Main 2016 (http://dx.doi.org/10.12946/gplh7).

Traslosheros, Jorge E., La reforma de la Iglesia del antiguo Michoacán: la gestión de fray Marcos Ramírez de Prado, 1640-1666, Morelia 1995.

Turrini, Miriam, La coscienza e le leggi. Morale e diritto nei testi per la confessione della prima età moderna, Bologna 1991.

Waldinger, Maria, "The long-run effects of missionary orders in Mexico", in Journal of Development Economics 127, issue C (2017) 355-378 (https://doi.org/10.1016/j.jdeveco.2016.12.010).

Yannakakis, Yanna, The Art of Being In-Between: Native Intermediaries, Indian Identity, and Local Rule in Colonial Oaxaca, Durham, NC 2008.

Yannakakis, Yanna, "Beyond Jurisdictions: Native Agency in the Making of Colonial Legal Cultures. A Review Essay", in Comparative Studies in Society and History 57:4 (2015), 1070-1082.

Yannakakis, Yanna and Martina Schrader-Kniffki, "Between the 'Old Law' and the New: Christian Translation, Indian Jurisdiction, and Criminal Justice in Colonial Oaxaca", in Hispanic American Historical Review 96:3 (2016), 517-548. 